\title{
THE IMPLEMENTATION OF T-EX APPROACH ON THE SHORT STORY TEACHNG IN EFL CLASS
}

\author{
${ }^{1}$ M G Maru \\ ${ }^{1}$ Universitas Negeri Manado, Indonesia \\ corresponding author: mrgidionmaru@unima.ac.id
}

\begin{abstract}
This research aims at applying the jeremiad approach in literary class particularly using short story for the purpose of finding a proper teaching design or model for character education. It is further hoped to obtain a teaching model on the text-based learning for the purpose of improving the quality of teaching of English as Foreign language (EFL) and the shaping of students' character. These purposes will be gained through qualitative inquiry which is marked by the involvement of students as the respondents and the researchers in its implementation. The students will be considered as the objects of this study. Those students involves in British and American Prose class in English Education Department, Universitas Negeri Manado. They will be taught using the Jeremiad Approach and later will be observed as well as interview. The data of the research are mostly taken from the result of interview and observation. The interview is done with the questions of how the shaping of their character as short story is used by combining it with the jeremiad approach. The observation is carried out through students' intellectual diary which is written in every meeting. The data are analyzed and coded in the way of Grounded Theory. The findings show the implementation of the T-Ex approach had provided students the opportunities to involve in active sharing and discussion within which they observed, questioned, tried, associated, comprehended, analyzed, created, presented, implemented, respected, experienced, and accepted as well as evaluated. In addition, the use of the students' intellectual diaries, a kind of daily note, contributed not only to monitor the advantage of the approach to the class but also alternatively to assess authentically students' absorption as well as competency outputs.
\end{abstract}

Keywords: T-Ex Approach, Shortstory, EFL Class, Character Education

\section{Introduction}

Teaching and learning activities are conducted as the attempts to build the wholeness of human being in the light of divine sublimity and meaningfulness. This proposition becomes one of the cores of the national education policy as translated into the 2013 curriculum. The educational process is not merely aimed at shaping the intellectual achievements but also establishing the spiritual ones. The teaching and learning activity comprise with the steps to meet learners' needs which are adapted into a certain standard of a graduate profile. It is then elaborated into the goals of the 
national education which mainly focus on the three aspects of competences namely attitude including spiritual and social ones, skill and knowledge as declared by The National Ministry of Education and Culture, Muhamad Nuh, in Harian Kompas, Kamis, 7 Maret 2013. At this circumstance, language, according to Nuh, "defines its essentiality in transferring the content of the material from all of the sources for learners' competencies". Hence, language plays as an integrating role for intersubjects in the national curriculum. The proper and correct use of language positions a text as the basis for learning.

It has been synthesized, "language always happens as text and not as isolated words and sentences" (Thornbury, 2005: 8). A text constitutes an arena for language exploration and elaboration. It is constructed by words formation and association in a certain context and interaction as well as information. The text can be viewed, then, as the object for language studies, information resources and creative works. This means that a text deserves to be the springboard for language learning since it highlights the use of a language in its unity; forms and functions. The language rises in its contextual application. In terms of English learning, a text does not merely open the path to elaborate the linguistic objects but also to implement English for communication. In other words, the text-based learning brings forth the practice of developing language skills in its immediate and close relationship to the sociocultural significances and multidisciplinary knowledge as well.

A jeremiad builds up its points through the application of the stages which put forward the idea of make meaning of the text and communicating it. The final aim of the stages can be defined as the expectation toward obtaining of particular attitude or skill related to the previous found knowledge or understanding. A jeremiad emerged from the effort to deal with the anticipation toward the potential of the lessening of the adherence to Puritanism in early America. This makes the substance of its construct to be inseparably pragmatic. It serves as "a type of chronicle or annals whose chief motivating force was to exhort a faltering people to mend its ways"(Burbank and Moore 1967,p.12 Maru, 2013,). In other words, the content of the jeremiad reflects the order of logic which combines the presentation of knowledge and the art of persuasion as well as the shaping of a certain attitude. Within this logic, a text in a jeremiad perspective has to be interpreted in three consecutive phases of presentation to the audience namely the lamentation of the present, the evocation of the past, and the calling for renewal. The first phase perceives a text as something comes from the present condition. It can portray the reality of moment of the text production. The text can be a reaction or response and the highlights of the ongoing circumstances. It might be explained by its background, atmosphere and type. At the same time, the text explains its context. The second phase urges the deep examination of the text which is carried out by connecting the context with knowledge such as multidiscplinary references, history, past figures, location, and Holy Book verses. These are intended to gain encouragement and solution for the current condition. The last stage is marked by the finding of moral values out of the text. The value discovery is crucial at this moment of interpretation since it is capitalized to suggest the enactment of a certain expected attitude. The value serves to be the basis for character development. Seeing these jeremiadic logics, the writer detects its link to the soul of the 2013 Curriculum that is integrating skill, knowledge and attitude. Therefore, these phases of logic are elaborated and 
translated into three parts of text explanation, examination and expectation for EFL context. The writer likes to call this teaching approach applying the jeremiad logic as T-Ex approach. This approach is regarded to be a potential alternative for EFL teaching as it works in the way of hermeneutics which is thought to be more suitable for language teaching compared to the scientific approach (Marsigit, 2013).

Unlike the order of stages in the scientific approach, the jeremiad approach relies upon three stages that concentrate on the use of the text in the classroom activities. The text becomes the center for teacher-student interaction. The absence of the text will turn out to be clueless activities. Once a text is introduced to students, it serves to be axial for the class to define its activity. The text is assumed as a bonanza whose advantages depend on the dialectic action performed in the classroom. This means that the teachers' creativity and students' participation should be part of the design or plan for learning activity. In other words, since creativity is mostly determined by the acquisition of knowledge and experience as well, teachers are required to be well-prepared, not only for English mastery but also other possibly related disciplines to the text used. It can be so due to the facts that even a single text is potential for pursuing the goals of learning; competencies related to skill, knowledge and attitude. A text acts as rich sources to develop knowledge and attitude, and practice students' integrative skill. It is assumed to be the media for exercising students' language mastery and exposing students to English in their interaction as well as setting up skill improvements. The selection has to be cautiously carried out. The criterion of a text must cover the possibility of English exposure and its relation to knowledge enrichment as well as character development. The text ought to spark the flames of language aspects and activities which burn out students learning practice and character. However, it is important to note that the effectiveness of using the text turns to the teachers' ability to bring it "down" to the class. Here lie the potentials of chipping in or associating certain part of the text with the things/issues within or outside it. The preparation becomes influential at this point. It can be stated that the use of this approach does not allow the space for unprepared teachers. For English class, the preparation includes the anticipation to unpredicted questions such as the questioning of meaning of the words, linguistics objects, idioms or terminologies found in the text and their associations.

Further, the text is also viewed to be the zero point at which teachers commence the interaction with students in terms of recounting ideas, references, figures and other issues. These constitute activity for mutual knowledge enrichment. In the practice of teaching English, the text is not only linked to the language knowledge but also engaged to other relevant disciplines. In so doing, the text based learning in the frame of this jeremiad approach or T-Ex approach involves knowledge sharing and enrichment. A text in this approach is also defined as the moral guide or attitudinal guide. It produces the values that organize an individual within a social interaction and a group within a group even larger community. Implicitly, the approach inspires certain attitude as the reflection of the comprehension of the text. It does not matter whether the text is short or long. The important thing is that teachers have to be the first figure to give an example of the implementation of the value. The activity in the classroom using the text must come to the revelation of moral values which prescribe the enactment of certain attitudes and, later, bring them into the daily context or future expectation both in the social 
and spiritual domain or both in the local and national scope and even in the international one.

Such conception is synthesized into three stages of a learning approach following ones that have been defined as the structure of the jeremiad. The three stages which are so-called the T-Ex approach are experimented as the practice of the text-based learning as suggested in the 2013 curriculum particularly in the learning of EFL. This is not apart from the synthesis of language that serves to be a binding tool to inter-subjects of the national curriculum. A text, within which language must be used correctly and properly, gains its fundamental position for learning (Mahsun, 2013). At this point, language is treated contextually. This implies that language grows within a certain social situation within its certain purpose and within certain academic uses. Under such reasoning, the three aspect of competencies namely attitude including spiritual and social ones, skill and knowledge in the 2013 curriculum are achieved by practicing the following activities;

\section{A. Text Explanation}

At this stage, the classroom activity is addressed to explain the existence of a text. Teacher in the interaction with students builds up the context of the text. If a speaker explains the ongoing situation is a crucial step in the creation of a jeremiad, a teacher in EFL class encourages discussions on the rise of the text including the background of the text, the kinds of text, and all of aspects that might be related to the creation of the texts. This is inspired by the jeremiad structural aspect of the lamentation of the present which interprets a text to be inseparable from the condition of the society, portrays a problem at hands, and defines its cause. Thus, the points of the jeremiad reflect the attempt to give the meaning to the situation faced by the society and the identification of its cause(s) (Maru, 2013). Similarly, the text used for EFL learning is introduced by the activity of identifying the text and trying to find the explanations related to the text creation. In this experimentation, the text explanation stage is designed in the following classroom activities;

-. Each student should be given a short story entitled "Beware of the Dog" by Roald Dahl in a week before.

-. In the first meeting, teacher facilitates the identification of the text by starting up with leading questions on the text existence. It is commenced by asking question related to the title, to the idea comes to their mind when reading the title of the short story, to the expectation or imagination when looking at the title for the first time, to the author, and to the time of writing. At this point, students have chances to exchange their ideas and impressions upon the text as well as began to recall their readings related to the story. The text functions as the starting point for critical activities. Each student is stimulated to think critically about the parts of the text.

-. Students are asked to retell the story. The teacher picks up students randomly as a strategy to check their reading and comprehension. Here, students comment upon the chronology of the story and, then, build up the plot including setting, characters. They might see that some parts of the story are missing in their classmates' recounting and add the missing ones. This activity is improvised by suggesting a puzzle game; and choosing certain parts of the story to be put in the right order by other students collaboratively. They are given time to discuss and share their opinion the accuracy and relation of the plot, setting, and characters. They may argue on the 
difference of their chronologies. The text serves as the instrument for the recounting assessment. Their reading and recounting ability were tested.

-. Having discussed the story, students are suggested to identify the issues which possibly come up from the story. This is the time to listen and dig out students' perception and thoughts as well as to expose their language skill, comprehension, and ability to relate the text into the context which is familiar to them or the period of the text production. The theme and atmosphere of the text including its background are intended to be the outputs of this phase. By which, the text existence was contextually explained. For students, they have the opportunity to interact with the text and with their friends, and surely to expose their language skill.

-. Teachers explore the questions of what, why, and how for the purpose of answering and finding the explanation about the text. It gives the information of what was happening contextually, what problem was faced both values/norms and textual, and what was the cause as well as the commentary (lamentation) on it. In terms of learning literature, the knowledge of literary elements is touched while, for the language learning, students are engaged in the exposure of their skills.

\section{Classroom facts}

Basing upon the observation and examination of the students' intellectual diaries, the writer illustrated the classroom activities as follows; the class was begun by the teacher randomly picked up students to retell the short story. Students recounted the story in slight different chronologies. The other students responded by pointing out the missing part(s) of the story and suggesting the corrections. This was done to confirm the students' reading. It took several minutes. It was followed by teacher's effort to facilitate the practice of re-observing (scanning/skimming) the text of the short story through asking such as what came to their mind when they first time read the title of the story or what was interesting when they looked at story for the first time. These questions drove the students to start responding and exchanging ideas or impressions about the content, plot, characters, setting, theme and author. Some expressed that the title reminded them of their experiences with dog in their childhood or as pets while some other were interested in the meaning of the title and curious to find a dog in the story. They, then, created questions to be answered by their friends. It was summarized in the following student's IDs;

After we had read "Beware of the Dog", today we learnt again about this story and asked some questions. First question came from Adam. He asked why a nurse was lying to Peter. Erick answered that it might be an order that she got from the commander. Ricky said that it was a war tactic since the story's setting was World War II. I tended to agree with Ricky since it was about war against Germany. Other question came from me. I asked them why Peter lost one of his leg. Some friends tried to reply but I only prefer to Olive's statement that it might be because of the dogfight or air war since Peter was a pilot. The other questions came from Cici about why the story was entitled so while there was no major part of the story about the dog. Eun responded that it was a sign of location. Olive added that it told Peter that It was in French, it was the enemy's place. The last question raised was what the difference was for Peter after and before he saw the expression "beware of the dog or gardeauchien". Tasya said that Peter started to be careful after seeing the sign, he realized that he was at enemy's hands. (Student 10's ID) 
These quotations from the diaries inform that the classroom activities were filled with students' attempt to ask and answer questions as well as to argue and to provide the details to support. Here, it was also revealed that, in this classroom, students were given opportunities to observe the text carefully, know, comprehend, question, associate and experiment ideas as well as analyze the situation of the text. These are surely followed by their ability to express, expose and present thoughts in English. They shared the result of their reading and discussed the comprehensions. Students recalled war atmosphere which led them to figure out and associate with other similar situations in reality. In addition, the above quotations of the diary also reflect how students involved in the sort of cooperative learning which they were mutually enriched. The discussion had given them time to give and take, to respect and tolerate differences in opinion. The use of the text had facilitated students to expose themselves toward English; they read, speak, listen (to classmates) and write in English. These can be inferred by examining the next parts of students' ID;

At first, I did not really like to read, but I began to feel awkward after failing to respond and to share some friends' questions of the story. It made me read it. I don't want to be silent. I read and tried to understand the story. Now, I can read quickly and discuss the storyline. Moreover, we were asked to remember or to find other similar stories to Beware of the Dog. It was rather difficult but loved to hear some friends associated it films. My writing got progress too because there were writing assignments such as identifying sentences and paragraph types, writing short essay from the lines of the story including our intellectual diaries. I also practiced my listening by focusing on my friends' questions and opinions, including lecturers' words. My speaking had more times to practice in every meeting because my class was always in the discussion. Sometimes we laughed at friends, but it's ok. We laughed each other (Student 18's ID).

These parts confirm that, in text explanation phase, students enjoyed times to develop language skills and knowledge in the classroom. Students saw the progress of their skill and realized their improvements. Their reflection as recorded in their ID provided a space for students to think over their authentic situation after the class. The class discussion seemed to train them to observe and to read quickly, to critically comprehend the text, and later to logically transform the ideas into their expressions or arguments. This colored the joy of the class since some might be "funny". Here, teacher took a crucial role to encourage and appreciate the interaction. Praising and motivating flourished the class. They found some relevant aspects to the existence of the text. However, it was important to note that students' willingness to read and language level might be the challenge for these activities as found in their IDs, "I do not really like to read (Student 18 ID)" or "It was not easy if we just read once (Student 8 ID). This means that teacher should be able to face this situation. It was seen in the class that some students who were not used to read appeared to have difficulty, not to mention their level of language skill and time allotted. At this point, teacher acted as a facilitator and motivator. The class ended up with the assignment for the next meeting including the reminder for the ID writing.

\section{B. Text Examination}

The basic proposition for this stage is derived from the belief in the second structure of a jeremiad which urges the interpretation has to reveal the needs to reconcile the 
past with the present situation for the possible resolution. The past is reclaimed as the model for the attempt to solve the present perils. The past values are evoked to bring the enlightenment to face the decline of the present society. The values could be in the form of knowledge of the spirits, perspectives, attitudes and even moments or event of the past as well as the religious and cultural precepts that may inspire the revelation of the solution for the ongoing problems (Maru, 2014). Bringing this structure into the learning activities, teachers are challenged to be able to encourage learners to discover references, knowledge, past frames or experiences or values and attitude, readings, and expressions of the great figures or founders, heroic deeds and events, and the holy books as well as the lessons from their environment or other disciplines. It clarifies that within this phase the class activity covers the deep examination of the text. Therefore, in this study, the classroom activities must be conducted as follows;

-. Students are again asked for a close reading activity and paying attention on the details of the text/story.

-. Students are facilitated to identify, share and discuss the important details of the text/story such as settings, references, and other related knowledge as well as links to other possible information from multi-disciplinary aspects. These activities provide students the times to explore their knowledge and to recall their readings. The students define the context of the text and contextualized it into their situation.

-. For the language aspect, students are led to the activity of identifying linguistics features such as grammar, parts of speech, idioms, and discussing cultural aspect embedded to certain expression as well as pointing out or recalling the text type, kinds of paragraph. The activities can be also combined with the reproduction of text through writing using the previous chosen parts of the story as the beginning of the text that they produce. This implies that, at the same time, the text plays a role as the springboard for another task. (Johns and Davies, 1983, p.9). By doing so, students were expected to have more times and spaces to practice, develop and build up their language skills.

-. The end of this phase is marked a holistic comprehension of the text. The interactions among teachers and learners using English color the attempt to dig out any relevant situations to the text. The short story has to be deeply examined. It then brought to more intense discussion and comprehensive understanding of the text by relying upon the use of English as a medium of communication.

\section{Classroom facts}

Continuing the previous activities and having asked to share their comprehension of the text in the previous phase, students were involved in exploring their language knowledge related to sentence and paragraph construction. They re-observed and examined the given text to look at the details. These details became the points to suggest students' task for writing essay or paragraph. The parts of the story served to be inspiring beginnings of their writing assignment. The students listened to their classmates' paragraph and laughed at their creativity. It allowed the rise of some kinds of paragraph such as narrative, descriptive, and procedure, and issues related to students' background knowledge or familiarity. The following citations from students' ID can be the clues. 
From this story of Road Dahl, in the beginning, I thought the hard water was bad water or something dangerous (like in Indonesia air keras?). but I learnt that it was different, moreover It was suggested by a doctor for our teeth. And I learnt about the meaning of "dogfight" that I know it fight between two or more dogs. But actually it describes the battle between two or more military aircrafts. The story happened in world in WW II in 1944, it reminded me of our Independence day in 1945. I learnt about a kind of text. There are narrative, recount, descriptive, explanation, expository text, procedure text...i just knew it when I searched in the internet while reading the story. (Students 8 IDs).

I am interested in my friend's, Nivita's opinion. She said that she read the story, it reminded her of Indonesian Independence Day in 1945 because the story told about WW II in 1944. (Student 21's ID).

After finishing arranging sentences (writing), we continued giving our opinions. My friend, Cici, said about health aspect. She said that the hard water mentioned in the story is good for our teeth. For example, it has been developed namely "Listerine". The other friend, Eun, told us about world war. Some friends, Adi and Ricky, connected the story with sport like soccer clubs in France and England. Erick gave his opinion that related to music aspect of the sound of Junkers 88 like music duet with bass. Because I dont want to be silent student, I said to my friends and lecturer that at first $i$ thought the dogfight is a fight with a dog, but I looked up in my dictionary and found that it means a fight between jets in the air. (Students 4's ID).

From these citations, it can be depicted that the classroom activities were filled by student interactions. They took part in the discussion and writing tasks. Their grammar knowledge was tested in student participation in the paragraph or sentence arrangement. Text was seen as the linguistic objects (Johns and Davies, 1983, p. 1). It mediated the language tasks. Students had chance to analyze the incidents of the text and recall their knowledge in variety of disciplines as well as associate them with similar circumstances. They got involve in sharing knowledge time both ones which were related to the story and the others were related to the general knowledge. They made use of resources including internet sources. It seemed to picture students' background knowledge, familiarity and surely language skill and interest.

This portrayed that the approach had provided students with the opportunities to elaborate and explore their skills and knowledge as well. By arguing, they had tried to make conclusion out of the mosaics of the story. They were able to pick up what they viewed as "something" meaningful such as names, location, object, ways and terminologies. These led the students to interdisciplinary and contextual perspective on the text. Such perspective became the bullets for students' insights during the class interactions.

The teacher worked as moderator and for little moments constituted a resource if it was necessary. Students looked to be more active and open to their classmates' information or searches. They developed their social interaction; respect other opinions, take and give ideas. They learnt and established a kind of mutual enriching communication. The knowledge sharing had bridged them to a sort of community interaction. This can be defined as the achievement of the text examination phase. Yet, the challenge for this phase seemed to emerge from the preparation and competence of a teacher. During the classroom interactions, students 
might come with unexpected comments, opinions and questions which mean that teacher should be well prepared both in terms of language skill and possibly relevant knowledge to the text. The class ended up by the assignment

\section{Text Expectation}

Following the lamentation of crisis or affliction and the looking back to the past, the call for renewal constitutes the other element of jeremiad (Murphy, 2009, p.9). This implies that creation of jeremiad is pragmatic. It prescribes the need to voice and to inspire a particular attitude or change. Being adapted to the practice of English language teaching, this approach proposes the finding of the pragmatic messages of a text. As the text goes through the explanation and examination phases, it has to come to an expectation. Like the jeremiad calling for renewal, a text may have an expectation within it. It recalls certain expected outputs. Having accomplished to comprehend a text and its context, the learners are hoped to gain certain skill and knowledge as well as attitude. In line with this formula, the classroom interactions are framed in the following activities;

-. Teacher require students to reflect upon of their discussion of the story and identify values emerged from the story/text.

-. The presentation of the values is suggested to be supported by clear arguments and data from the story. In this part, students were pushed to keep on thinking critically and shared their perspective with the classmates. This leads to the general conclusion at the end of the discussion.

-. Students have to involve in the discussion on how the invented values are relevant to the current context and future expectation for both social and spiritual ones.

-. Out of the invented values, students are driven to figure out proper attitude as the consequence of the found values. This was meaningful to contextualize the text for not only the academic purpose but also for social interaction and experience.

-. It is important to note that these stages of the jeremiad approach or T-Ex approach constitutes a unity of learning activity which demands a well-prepared and creative teacher. The student interactions with their peers were crucial aspects and teachers were challenged to be able to encourage and facilitate the exchange of ideas using correct and proper English.

\section{Classroom Facts}

Continuing the class activities related to the exploration of relevant knowledge and references, the students were encouraged to define values which are inspired from the text. The teacher stimulated the question of values by pointing one of the students and challenged responses from other students. The students obtained the time to exchange interpretations again. The activity can be evaluated from some students' ID bellow.

In my opinion there are many moral values that we can take from the short story, "Beware of the Dog". Like some of my friends told us in the class, it is about hope, what will happen, life must go on. Sometimes we have to save our problems just for ourselves, never give up. So I think that anything happens in our life, we have to keep believing and being optimistic that we can go through it all (Student 2 ID)

From the sharing time; I learnt about; Spirit as Hendrik said, "In this story, Peter was in the bad situation. He lost one of his leg and was in the enemy territory. But he 
never gives up. He still had the spirit to go out of the situation". Hope; some of my friends saw hope. Nationalism; Nivita said, "the World War II reminded me about Independence Day of Indonesia because it came close to Indonesian Independance..." (Student 9 ID)

From these IDs, the class interaction was flourished with the attempts to dig out values of the story. The students presented their inferences. They used their language skill to analyze the story supported by their knowledge taken from their readings and context of their life. It seemed that they put forward the analysis based upon the story and its context, and then connects their interpretation with the context of their life. They came to the values such as nationalism which is actually the theme of the story, optimism and hope as well as encouragement. These values appeared to inspire students for the attitudes which they tried to frame to their life. Being optimistic at times of hardship and keeping hope for a better situation emerged to be dominant attitudes. These reflected their spiritual attitude in the sense they showed their faith in the providence of better future for people and social attitude in terms of displaying positive characteristics which are meaningful for social interactions. Teacher also had chances to chipped-in and established students' character. This implies that the classroom activity had covered the exposure of language skill since all of the interactions were carried out in English, and by using English, students were engaged to elaborate and explore all of the possibly relevant knowledge as well as the implementation of the character education. The class ended with students' assigned with the final ID and paper for exam.

\section{Conclusion And Suggestion}

The experimentation of the jeremiad approach or T-Ex approach in the teaching of English revealed that it was contributive and meaningful in meeting the demand of students' need to practice and expose themselves in English as the reflection of the three competencies namely skill, knowledge, and attitude. The students ID presented the facts that the implementation of the T-Ex approach had provided students the opportunities to involve in active sharing and discussion within which they observed, questioned, tried, associated, comprehended, analyzed, created, presented, implemented, respected, experienced, and accepted as well as evaluated. In addition, the use of the students' intellectual diaries, a kind of daily note, contributed not only to monitor the advantage of the approach to the class but also alternatively to assess authentically students' absorption as well as competency outputs. However, the main challenge for this approach seemed to be teachers' preparation and mastery of the text or material particularly to anticipate unpredicted comments or questions when it comes to the text examination phase. The other challenge might be the question of proper time allotment since it is related to the expected output of every phase. It depends upon teacher's capacity in both knowledge and class management. Therefore, as a preliminary experimentation, this approach needs to test in the variety of class size and text types. It is suggested that more experimentations and elaborations of this approach in non-narrative texts will be useful in the attempt to give alternative and assistance for English teachers to achieve the competencies required by the 2013 curriculum.

\section{References}


Journal of Educational Method and Technology Vol. 2 No. 1, April 2019

P-ISSN 2622-8459 E-ISSN 2622-8467

http://ejournal.unima.ac.id/index.php/jemtec

Bellah, Robert. (1992). The Broken Covenant: American Civil Religion in Time of Trial. Chicago: The University of Chicago Press.

Burbank, Rex J, and Moore, Jack B. (Eds) (1967). The Literature of Early America. Columbus: Charles E Merril Books, Inc

Collie, J. and S. Slater. (1990). Literature in the Language Classroom: A Resource Book of Ideas and Activities. Cambridge: CUP.

Elliot, Emory, (2002) Early American Literature. New York: Cambridge University Press.

Johns, T. \& Davies, F. (1983). Text as a Vehicle for Information: the Classroom Use of Written Texts in TeachingReading in a Foreign Language. Reading in a Foreign Language, 1, 1-19.

Lemay, J.A Leo (Ed). (1988). An Early American Reader. Washington, D.C: United States Information Agency.

Madsen,Deborah. (1998). American Exceptionalism. Jackson: University Press of Mississippi.

Mahsun, "Pembelajaran Teks Dalam Kurikulum 2013", kemdikbud.go.id/kemdikbud/artikel-kurikulum-mahsun.

Marsigit, "Tantangan dan Harapan Kurikulum 2013 Bagi Pendidikan Matematika", Seminar Nasional Matematika dan Pendidikan Matematika, Selasa, 18 Juni 2013 Maru, Mister Gidion, (2013) “Jeremiad Frames in Reagan's Inaugural Address", Jurnal Humaniora (UGM) Vol 25, No 1, Februari 2013.

Miller, Perry. (1953). The New England Mind, From Colony to Province. USA: Harvard University Press.

Murphy, Andrew R. (2009). Prodigal Son: Moral Decline and Divine Punishment from New England to 9/11. New York: Oxford University Press

Nuh, Mohammad, "Kurrikulum 2013”, Kompas, 7 Maret 2013

Smith, Craig Allen, and Kathy B Smith. (1994). The White House Speaks: Presidential Leadership as Persuasion. West Port: Praeger Publisher

Thornbury, S. (2005). Beyond the Sentence: Introducing Discourse Analysis. Oxford: Macmillan Education.

Thornberg, Robert , Informed grounded theory, 2012, Scandinavian Journal of Educational Research, (56), 3, 243-259. 